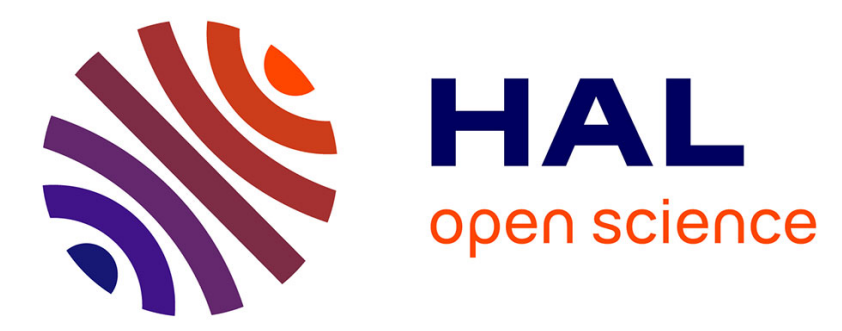

\title{
Experimental determination of creep properties of zirconium alloys together with phase transformation
}

Djillali Kaddour, Stéphane Frechinet, Anne-Françoise Gourgues-Lorenzon, Jean-Christophe Brachet, L. Portier, André Pineau

\section{- To cite this version:}

Djillali Kaddour, Stéphane Frechinet, Anne-Françoise Gourgues-Lorenzon, Jean-Christophe Brachet, L. Portier, et al.. Experimental determination of creep properties of zirconium alloys together with phase transformation. Scripta Materialia, 2004, 51 (6), pp.515-519. 10.1016/j.scriptamat.2004.05.046 . hal-00166052

\section{HAL Id: hal-00166052 https://hal.science/hal-00166052}

Submitted on 9 Oct 2017

HAL is a multi-disciplinary open access archive for the deposit and dissemination of scientific research documents, whether they are published or not. The documents may come from teaching and research institutions in France or abroad, or from public or private research centers.
L'archive ouverte pluridisciplinaire HAL, est destinée au dépôt et à la diffusion de documents scientifiques de niveau recherche, publiés ou non, émanant des établissements d'enseignement et de recherche français ou étrangers, des laboratoires publics ou privés. 


\title{
Experimental determination of creep properties of Zirconium alloys together with phase transformation
}

\author{
D. Kaddour ${ }^{\text {a }}$, S. Frechinet ${ }^{\text {a }}$, A.F. Gourgues ${ }^{a, *}$, J.C. Brachet ${ }^{b}$, L. Portier ${ }^{b}$, A. Pineau ${ }^{a}$ \\ ${ }^{a}$ Ecole des Mines de Paris, Centre des Matériaux, UMR CNRS 7633, BP 87, 91003, Evry Cedex, France \\ b CEA Saclay, DEN/DMNISRMA, 91191 Gif-sur-Yvette Cedex, France
}

The temperatures of $\alpha \rightarrow \beta$ transformation for the Zircaloy- 4 and $\mathrm{Zr}-1 \% \mathrm{NbO}$ alloys were determined using resistivity, calorimetry, image analysis and thermodynamic equilibrium calculations. The experimental and calculated results were found to be in good agreement. The steady state creep behavior was then determined in the single phase and $(\alpha+\beta)$ phase temperature ranges. Finally, the creep results for both alloys were modeled and summarized into deformation-mechanism maps.

Keywords: Creep; Phase transformations; Zirconium alloys

\section{Introduction}

Zirconium alloys are widely used for the fabrication of fuel cladding tubes for nuclear reactors (e.g. PWR, VVER, RBMK, Candu). In equilibrium conditions, these alloys undergo a phase transformation $\alpha$ (hcp) $\rightarrow \beta$ (bcc) between 800 and $1000{ }^{\circ} \mathrm{C}$ for the Zircaloy-4 (Zy-4) alloy [1] and between 600 and $1000{ }^{\circ} \mathrm{C}$ for the $\mathrm{Zr}-$ $1 \% \mathrm{NbO}$ alloy [2]. On heating, this transformation is accompanied by a slight volumic contraction [3,4]. For technical reasons, it is necessary to establish the mechanical properties of cladding tubes, in particular in the temperature range corresponding to phase transitions. The high-temperature $\beta$ phase is known to be "softer" than the low temperature $\alpha$ phase, therefore it is important to know its creep mechanical behavior at low stres-

\footnotetext{
${ }^{*}$ Corresponding author. Tel.: +33-1-6076-3066; fax: +33-1-60763150 .

E-mail address: anne-francoise.gourgues@ensmp.fr (A.F. Gourgues).
}

ses. However, few literature data are available yet. The existing results are given only in the $\alpha$ domain [5-7].

Due to the low solubility of niobium in zirconium at low temperature, the $\mathrm{Zr}-1 \% \mathrm{NbO}$ alloy contains a few percents of $\beta$ phase even at low temperature. This low amount of $\beta$ phase, found as small, dispersed particles, does not affect the low temperature mechanical behavior of the $\mathrm{Zr}-1 \% \mathrm{NbO}$ alloy, so that the low-temperature domain $(\alpha+a$ few percents of dispersed $\beta$ phase) will still be denoted as the " $\alpha$ domain" throughout the paper.

This study aims at providing experimental creep data over a wide temperature range in both the $\alpha,(\alpha+\beta)$, and $\beta$ phase conditions and, together with existing literature data, at building deformation-mechanism maps for $\mathrm{Zy}-4$ and $\mathrm{Zr}-1 \% \mathrm{NbO}$ similar to that already published for pure zirconium [8]. These maps also include experimental data already published in the literature. It is worth noting that these maps are built from mechanical tests performed under secondary vacuum in order to avoid any oxidation effect, which is known to strengthen the $\mathrm{Zr}$ base matrix. 


\section{Materials}

Two zirconium alloys were provided as fuel cladding tubes with an outer diameter of $9.50 \mathrm{~mm}$ and an inner diameter of $8.36 \mathrm{~mm}$. The first alloy was a stress-relieved Zy-4 with equiaxed grains of a mean size of $8 \mu \mathrm{m}$, whose chemical composition is typically: $\mathrm{Sn}: 1.5, \mathrm{Fe}: 0.2, \mathrm{Cr}$ : 0.1 , O: 0.1 (weight $\%$ ), with a melting point of 1847 ${ }^{\circ} \mathrm{C}$. The second alloy was recrystallized $\mathrm{Zr}-1 \% \mathrm{NbO}$ with equiaxed grains of a mean size of $5 \mu \mathrm{m}$, whose chemical composition was typically $\mathrm{Nb}: 1, \mathrm{O}: 0.14$ (weight \%), with a melting point of $1865{ }^{\circ} \mathrm{C}$. This temperature was calculated with the Thermocalc ${ }^{\circledR}$ software in equilibrium conditions using the Zircobase ${ }^{\circledR}$ database established by Dupin et al. [9].

\section{Experimental procedures}

\subsection{Creep tests}

The creep tests were carried out using an electricalmechanical machine under load control, the tubes being tensile loaded along the axial direction. Heating was performed using a $6 \mathrm{~kW}$ radiation furnace inside a high vacuum chamber under $10^{-3}-10^{-4} \mathrm{~Pa}$. The temperature was monitored using $\mathrm{Pt} / \mathrm{Pt}-10 \% \mathrm{Rh}$ (S-type) thermocouples spot-welded on the center part of the specimen. The axial elongation was continuously measured during the test using a contactless laser extensometer (due to the softness of the $\beta$ phase). The $25-30 \mathrm{~mm}$ gage length was delimited using two alumina rings, which were cement-pasted onto the tube. The load was monitored using a $2 \mathrm{kN}$ water cooled load cell located inside the vacuum chamber. During creep tests, effects of loading history were investigated by increasing, then decreasing load levels by small steps. This was necessary because the evolution of microstructure e.g. recrystallization of the $\alpha$ phase in stress-relieved $\mathrm{Zy}-4$, or $\beta$ grain growth, could have influenced the creep behavior of both alloys.

Electrical resistivity measurements were used to continuously monitor the phase transformation by using the four point direct current potential drop method, with platinum wires spot welded onto the specimen surface. The amounts of $\alpha$ and $\beta$ phases were calculated from the measurements using the level rule, after having fitted polynomial functions of degree 3 to the experimental data for the $\alpha$ phase domain [10] and linear functions in the single $\beta$ phase domain.

\subsection{Validation of phase transformation monitoring}

Monitoring of phase transformation by the resistivity technique was validated by comparison of results from calorimetry tests, metallographic observations and thermodynamic equilibrium calculations.
Differential scanning calorimetry tests were performed using a Multi Detector High Temperature (Multi-HTC Setaram) apparatus with heating and cooling rates of $10{ }^{\circ} \mathrm{C} / \mathrm{min}$ and a maximum temperature of $1200{ }^{\circ} \mathrm{C}$. These tests were carried out under primary vacuum.

Conventional etching techniques and optical microscopy were used to investigate the microstructure of $\mathrm{Zr}-$ $1 \% \mathrm{NbO}$ alloy after both creep tests and interrupted heating cycles. In the case of $\mathrm{Zy}-4$, the former $\beta$ phase could not be easily distinguished from the untransformed $\alpha$ phase after rapid cooling, due to its low hardenability. For the $\mathrm{Zr}-1 \% \mathrm{NbO}$, conventional image analysis was used to quantify the amount of "ex" $\beta$ phase: the bainitic former $\beta$ phase appears different from the equiaxed untransformed $\alpha$ phase after annealing for at least $30 \mathrm{~min}$ (i.e. less than the creep test duration) at various temperatures in the $(\alpha+\beta)$ domain followed by cooling at $200{ }^{\circ} \mathrm{C} / \mathrm{min}$.

Equilibrium calculations were carried out with the Thermocalc ${ }^{\circledR}$ software using the Zircobase ${ }^{\circledR}$ database established by Dupin et al. [9] taking into account the specific chemical composition of both alloys.

\section{Results and discussion}

\subsection{Validation of phase transformation monitoring}

Fig. 1 shows resistivity and dilatometry curves of the $\mathrm{Zr}-1 \% \mathrm{NbO}$ alloy for the same heating and cooling rates $\left(V_{\mathrm{c}}=V_{\mathrm{r}}=50^{\circ} \mathrm{C} / \mathrm{min}\right)$. This figure shows that during heating, in contrast to the bulk contraction usually observed due to the $\alpha \rightarrow \beta$ phase transformation, an axial expansion was observed. This is due to texture-induced anisotropy effects, as explained elsewhere [4].

The transformation temperatures of both alloys were first determined by the resistivity technique. They were then compared to results from calorimetric tests for the Zy-4 alloy (Fig. 2a), and from calorimetric tests,

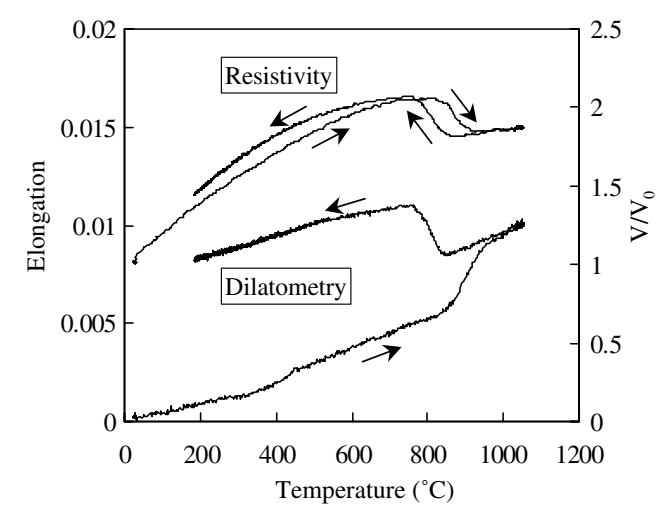

Fig. 1. Resistivity and dilatometry curves $\left(\mathrm{Zr}-1 \% \mathrm{NbO}, 50^{\circ} \mathrm{C} / \mathrm{min}\right) . V$ is the DC potential, of initial value $V_{0}$. 

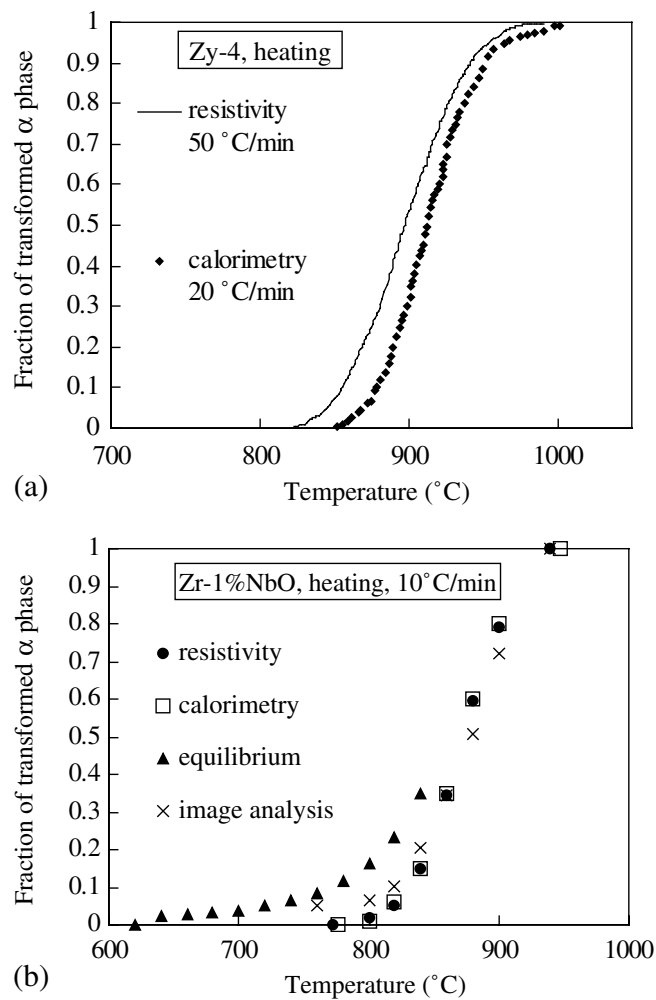

Fig. 2. Fraction of transformed $\alpha$ phase versus temperature, for (a) $\mathrm{Zy}-4$ and (b) $\mathrm{Zr}-1 \% \mathrm{NbO}$.

image analysis and equilibrium calculations for the $\mathrm{Zr}-$ $1 \% \mathrm{NbO}$ alloy (Fig. 2b).

The starting temperature of the $\alpha \rightarrow \beta$ transformation, calculated by the resistivity technique, is about $820{ }^{\circ} \mathrm{C}$ for the $\mathrm{Zy}-4$ alloy and $770{ }^{\circ} \mathrm{C}$ for the $\mathrm{Zr}-$ $1 \% \mathrm{NbO}$ alloy. Experimental measurements using both three techniques agree very well. The shift observed in the beginning of the $\alpha \rightarrow \beta$ transformation between experimental measurements and equilibrium calculations is due to the well-known "overheating effect" on the incubation time of diffusion controlled phase transformation for out of equilibrium heating conditions [1].

According to the results presented in Fig. $2 \mathrm{a}$ and b, in situ monitoring of phase transformation by resistivity technique was considered to be valid for both alloys. This technique was then used all along the creep tests.

\subsection{Creep results}

Before presenting the results of creep tests it should be indicated that the fraction of transformed $\alpha$ phase was observed to be constant during the creep tests, when the materials were tested in the two-phase domain. Moreover, no "thermal or mechanical history effect" could be detected in the creep tests (Fig. 3a), the steady-state true strain rate (which was always almost
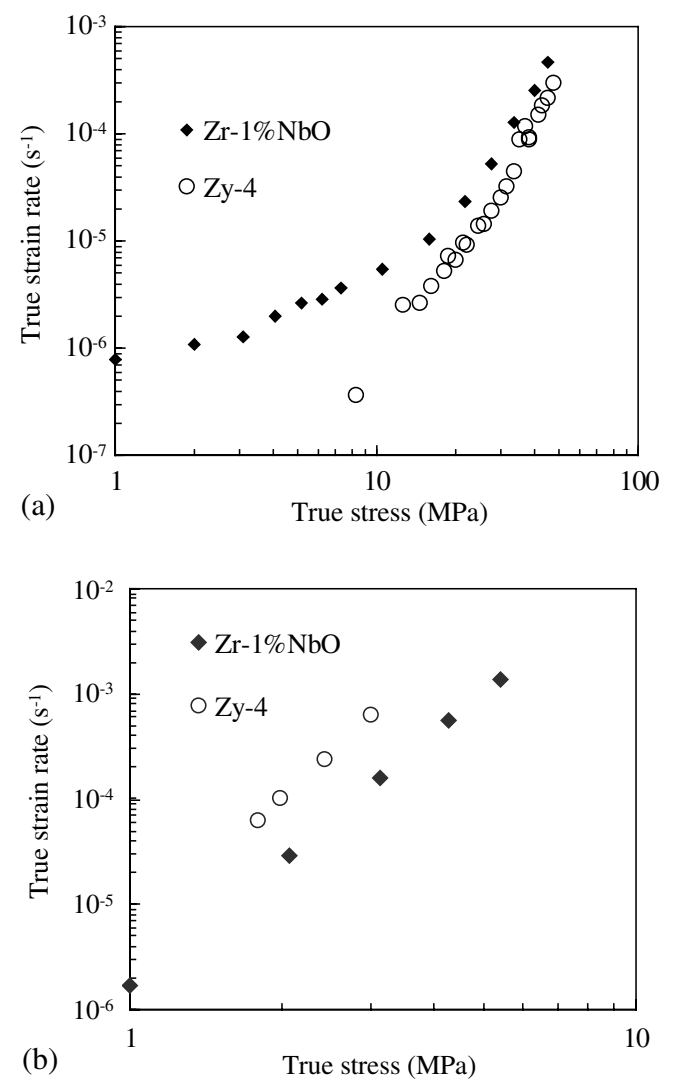

Fig. 3. Stress dependence of the strain rate for the two zirconium alloys. (a) $T=700{ }^{\circ} \mathrm{C}$, data for both increasing and decreasing load levels showing no history effect. (b) $T=1000{ }^{\circ} \mathrm{C}$.

immediately achieved) was the same in loading and in unloading conditions.

In the $\alpha$ and $\beta$ phase domains, examples of creep results for the two alloys are given in Fig. 3. The creep behavior of the two alloys (in the $\alpha$ domain and $\beta$ domain) was then described by the power-laws [11]:

$\dot{\varepsilon}=\frac{A}{T} \sigma^{n} \exp \left(-\frac{Q}{R T}\right)$

The value of parameters $A, n$, and $Q$ appearing in Eq. (1) are given in Table 1 for $\dot{\varepsilon}$ in $\mathrm{s}^{-1}, \sigma$ in $\mathrm{MPa}$ and $T$ in $\mathrm{K}$.

In the $\alpha$ phase domain $\left(T<770{ }^{\circ} \mathrm{C}\right.$ for the $\mathrm{Zr}-1 \% \mathrm{NbO}$ and $T<820{ }^{\circ} \mathrm{C}$ for the $\left.\mathrm{Zy}-4\right)$ the results show two creep regimes. At low stresses $(\sigma<15 \mathrm{MPa})$, the creep exponent $(n \cong 1)$ suggests that the deformation mechanism could be "diffusion creep" while at higher stresses $(\sigma>15 \mathrm{MPa})$, the deformation mechanism is most probably "dislocation creep", since the value of $n$ ranges between 4 and 5 .

In the $\beta$ domain, only one regime is observed which is "dislocation creep" ( $n \cong 4)$.

It is difficult to refer to literature data concerning activation energies in $\alpha$ and $\beta$ phase for the two alloys. Several authors found widely different values, whatever 
Table 1

Creep parameters of $\mathrm{Zr}-1 \% \mathrm{NbO}$ and $\mathrm{Zy}-4$

\begin{tabular}{|c|c|c|c|c|c|c|}
\hline \multirow{2}{*}{$\begin{array}{l}\text { Material } \\
\text { Creep parameters }\end{array}$} & \multicolumn{3}{|l|}{$\mathrm{Zr}-1 \% \mathrm{NbO}$} & \multicolumn{3}{|l|}{$\mathrm{Zy}-4$} \\
\hline & $A\left(\mathrm{KMPa}^{-n} \mathrm{~s}^{-1}\right)$ & $n$ & $Q(\mathrm{~kJ} / \mathrm{mol})$ & $A\left(\mathrm{KMPa}^{-n} \mathrm{~s}^{-1}\right)$ & $n$ & $Q(\mathrm{~kJ} / \mathrm{mol})$ \\
\hline$\alpha$ creep $(\sigma<15 \mathrm{MPa})$ & $6.78 \times 10^{3}$ & 1.0 & 133 & $1.00 \times 10^{6}$ & 1.3 & 190 \\
\hline$\alpha$ creep $(\sigma<15 \mathrm{MPa})$ & $2.28 \times 10^{3}$ & 4.0 & 194 & $1.63 \times 10^{8}$ & 5.0 & 316 \\
\hline$\beta$ creep & $1.23 \times 10^{3}$ & 4.3 & 142 & $1.00 \times 10^{4}$ & 4.25 & 150 \\
\hline$(\alpha+\beta)$ creep & & 1.4 & & & 1.3 & \\
\hline
\end{tabular}

the creep mechanism, ranging from 88 to $315 \mathrm{~kJ} / \mathrm{mol}$ $[8,12-21]$.

The creep behavior of both alloys (Fig. 4) in the $(\alpha+\beta)$ domain is more complex than in the single phase domains. No simple constitutive equation could be identified. For a low applied stress (1 or $2 \mathrm{MPa})$, strain rates in the $(\alpha+\beta)$ domain are significantly higher than those measured in the single phase domains and even for the high temperature tests on pure soft $\beta$ phase. The creep exponent $(n \cong 1)$ suggests than in the $(\alpha+\beta)$ domain the deformation mechanism could be controlled by "interphase interface sliding". Due to this complex behavior, only a power-law of the type $\dot{\varepsilon}=B \sigma^{n}$ with temperature-dependent parameters $B$ and $n$ was fitted to the experimental results in the two-phase domain.

By comparing the two alloys it appears that in the absence of significant oxidation effects, the $\mathrm{Zr}-1 \% \mathrm{NbO}$ alloy is more resistant to creep than Zy-4 in the hightemperature $\beta$ phase domain, and a little less resistant in the $\alpha$ and $(\alpha+\beta)$ phase domains. However, one must keep in mind that, in practice, these alloys should be heated in a more or less oxidizing environment, and thus, that the strength of oxidized $\mathrm{Zr}-1 \% \mathrm{NbO}$ alloy should be higher than that of not oxidized alloys.

Fig. 5 summarizes the experimental results together with literature data and power-law models as deformation-mechanism maps. To the authors' knowledge, such maps are here published for the first time concerning

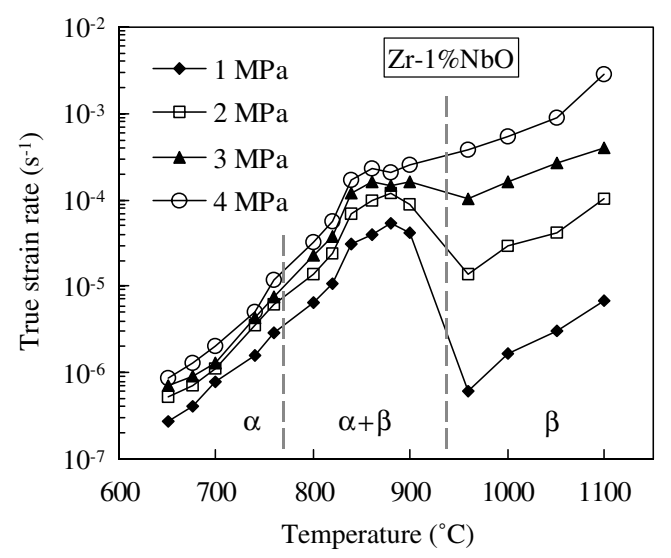

Fig. 4. Variation of the strain rate according to temperature.
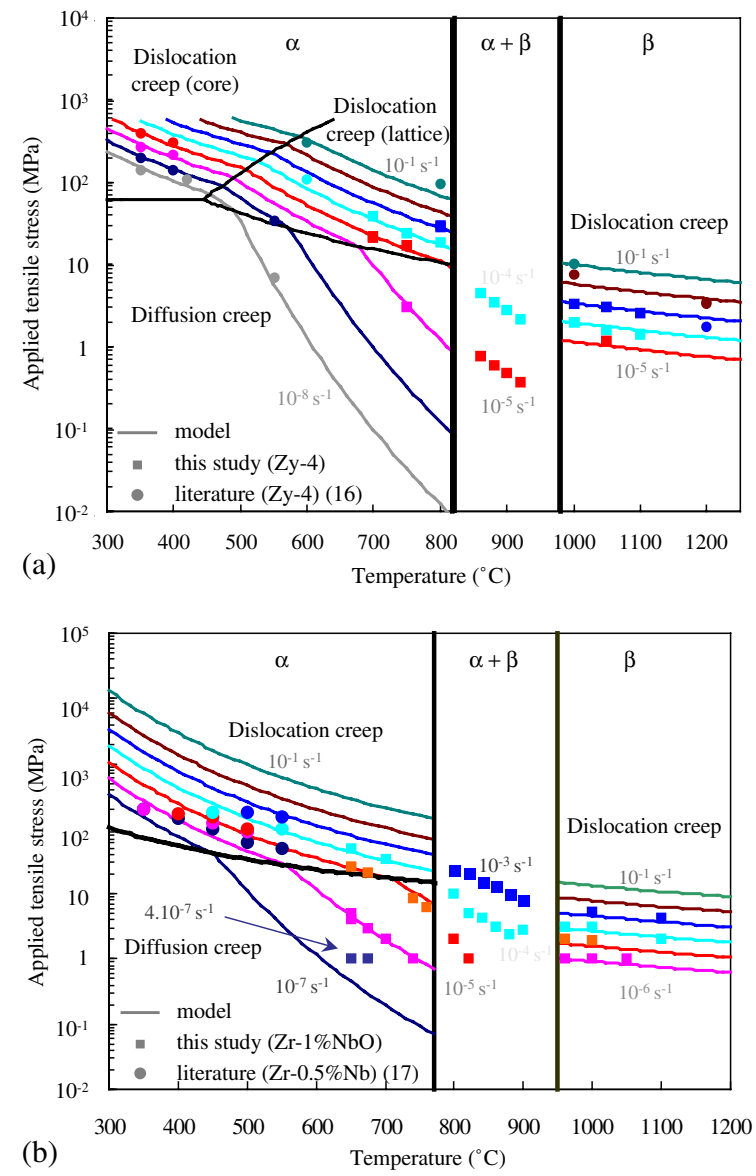

Fig. 5. Deformation-mechanism maps for (a) $\mathrm{Zy}-4$ and (b) $\mathrm{Zr}-$ $1 \% \mathrm{NbO}$. Lines of constant true axial strain rate are plotted using the model presented in this paper.

these industrial alloys. Note that only axial stresses and strain rates are displayed. The relative difference between calculated creep strain rate and experimental results is always less than $25 \%$.

The results of the present study are in good agreement with literature data and with the deformationmechanism map established by Sargent and Ashby [8] for pure zirconium. In particular, in these zirconium alloys, in the $\alpha$ domain, two mechanisms corresponding to diffusion and dislocation creep are observed, as in pure zirconium. In the same way, only dislocation creep occurs in the $\beta$ phase domain. 


\section{Conclusions}

1. A deformation-mechanism map has been established for both $\mathrm{Zy}-4$ and $\mathrm{Zr}-1 \% \mathrm{NbO}$ alloys.

2. In the single phase domains, the creep behavior was successfully described by the classical power-law equations. This was not the case in the two-phase $(\alpha+\beta)$ domain, where modeling of high creep rates under low stresses requires further investigation.

\section{Acknowledgments}

The authors would like to give special thanks to M. Rousselot for his technical support and precious advises. Technical assistance from J. Heurtel for mechanical testing, T. Guilbert ${ }^{1}$ for calorimetry tests and from C. Toffolon ${ }^{1}$ for equilibrium calculations is gratefully acknowledged.

\section{References}

[1] Forgeron T, Brachet JC, Barcelo F, Castaing A, Hivroz J, et al. ASTM STP 1354. West Conshohocken, PA: ASTM International; 2000. p. 256.

[2] Abriata JP, Bolcich JC. Bull Alloy Phase Diagrams 1982;3:28.

[3] Miquet A, Charquet D. J Nucl Mater 1982;105:132.
[4] Brachet JC, Béchade JL, Castaing A, Jouen T, Le Blanc L. Mater Sci Forum 1998;273:529.

[5] Thorpe WR, Smith IO. J Nucl Mater 1978;75:209.

[6] Brenner R, Béchade JL, Castelnau O, Bacroix B. J Nucl Mater 2002;305:175.

[7] Linga Murty K, Witarmo JR. J Nucl Mater 1995;156:359.

[8] Sargent PM, Ashby MF. Scripta Metall 1982;16:1415.

[9] Dupin N, Ansara I, Servant C, Toffolon C, Lemaignan C, Brachet JC. J Nucl Mater 1999;275:287.

[10] Canay M, Danon CA, Arias D. J Nucl Mater 2000;280: 365.

[11] Ashby MF, Frost HJ. Deformation-mechanism maps. Oxford: Pergamon Press; 1982.

[12] Hayes TA, Kassner ME, Rosen RS. Metall Mater Trans A 2002;33A:373.

[13] Prasad N, Malakondaiah G, Rao PR. Trans Indian Inst Met 1989;42:165.

[14] Pahutova M, Hostinsky T, Cadek J. Kovove Mater (in Czech) 1975;13:390.

[15] Donaldson AT, Ecob RC. Scripta Metall 1985;19:1313.

[16] Rosinger HE, Bera PC, Clendening WR. J Nucl Mater 1979;82:286.

[17] Pahutova M, Cerny V, Cadek J. Kovove Mater (in Czech) 1976;143:252.

[18] Malakondaiah G, Prasad N, Rao PR. Scripta Metall 1982;16: 421.

[19] Christodoulou N, Turner PA, Tome CN, Chow CK, Klassen RJ. Metall Mater Trans A 2002;33A:1103.

[20] Gilbert ER, Duran SA, Bement AL. ASTM STP 458. West Conshohocken, PA: ASTM International; 1969. p. 210.

[21] Stephan M, Adam E, Wetzel L. Kerntechnik 57 (in German) 1992;2:129.

\footnotetext{
${ }^{1}$ CEA-Saclay, DEN/DMN/SRMA/LA2M.
} 